\title{
Antifungal activity of Moringa oleifera leaves crude extract against Aspergillus flavus and Rhizopus stolonifer
}

\author{
*1Suraka, B., ${ }^{2}$ Ibrahim, D., ${ }^{3}$ Suleman, K., \\ ${ }^{4}$ Usman, U. and ${ }^{5}$ Usman, S.I. \\ ${ }^{* 1}$ Department of Microbiology and Biotechnology, \\ Faculty of Sciences, \\ Federal University Dutse, Nigeria. \\ ${ }^{2}$ Department of Integrated Science, \\ Federal College of Education Zaria, Kaduna state. \\ ${ }^{3}$ Department of Biological Sciences, \\ Faculty of Life Sciences, \\ Bayero University Kano, Nigeria. \\ ${ }^{4}$ Department of Biology, \\ School of Sciences, \\ Jigawa State College of Education, Gumel.
}

${ }^{5}$ Center for Advance Medical Research and Training, Usman Danfodio University Sokoto, Nigeria.

Email: bsaujara@gmail.com

\begin{abstract}
Moringa oleifera leaves crude extract have been reported to have an invitro antifungal potential on various species of fungi. Therefore, this study was conducted in finding out the invitro effects of methanol and ethanol extracts of Moringa oleifera leaves on some fungal species (Aspergillus flavus and Rhizopus stolonifer). The fungal species were isolated from contaminated bread on sabouraud dextrose agar (SDA) using agar plate method and microscopic exanimation at Microbiology Laboratory, Federal University Dutse. Moringa oleifera leaves were collected from Federal University Dutse botanical garden, they were processed and extracted using Maceration method. The extracts were screened at varaying concentrations $(25 \mathrm{mg} / \mathrm{ml}, 50 \mathrm{mg} / \mathrm{ml}, 100 \mathrm{mg} / \mathrm{ml}, 150 \mathrm{mg} / \mathrm{ml}$ and $200 \mathrm{mg} / \mathrm{ml})$ for their antifungal activity against the test organisms. Aspergillus flavus was more susceptible to the extracts with high mean zone of inhibition of $12.80 \pm 0.20 \mathrm{~mm}$ for methanolic extract and $11.40 \pm$ $0.10 \mathrm{~mm}$ for ethanolic extract compared to Rhizopus stolonifer with $9.66 \pm 0.33 \mathrm{~mm}$ for methanolic extract and $8.67 \pm 0.10 \mathrm{~mm}$ for ethanolic extract. Minimum inhibitory concentrations of the extract were determined with varying effectiveness of $75 \mathrm{mg} / \mathrm{ml}$ for Aspergillus flavus and $100 \mathrm{mg} / \mathrm{ml}$ for Rhizopus stolonifer. This study showed credence to the traditional use of Moringa oleifera leaves in the treatment of diseases caused by Aspergillus flavus and Rhizopus stolonifer.
\end{abstract}

Key words: Aspergillus flavus, Invitro, Moringa oleifera, Rhizopus stolonifer. 


\section{INTRODUCTION}

The products obtained from different parts of herbs and trees, being a source of several therapeutic agents and bioactive compounds, are relatively considered safe for human consumption (Stohs and Hartman, 2015).Food and Agriculture Organization's (FAO) reported that; about $70-80 \%$ of the global population, especially in developing and low to middle income countries, relies on herbal medicine that is used to prevent and treat diseases (Ekor, 2014), and almost $25 \%$ of the synthesized drugs are manufactured from medicinal plants (Pan et al., 2013). Moringa oleifera commonly known as the 'drumstick' or 'horseradish' tree, it is a member of the family Moringaceae, Almost each and every part of Moringa tree is useful for diseases treatment, functional food preparations, nutraceuticals, purification of water, and production of biodiesel which include roots, leaves, flowers, green pods, and seeds (Saini, 2015).

The most broadly cultivated species of Moringa in Northwestern India, Africa and Asia is Moringa oleifera from the genus Moringa in the family Moringaceae (Padayachee et al., 2012). It made up of 13 species from tropical and subtropical climates, ranging in size from tiny herbs to big tree. Moringa oleifera tree posses a great number of bioactive compounds (Saini et al., 2014; Martin et al., 2013). Among distinctive parts of the plant the leaves are the most frequently used part, which are rich in Vitamins, Carotenoids, Polyphenols, Phenolic acids, Flavonoids, Alkaloids, Glucosinolates, Isothiocyanates, Tannins and Saponins. The richness in terms of bioactive compounds might explain "the antimicrobial properties" of Moringa oleifera leaves. Many studies in vitro and in vivo have reported these antimicrobial properties (Leone et al., 2015).Inhibitory effect of Moringa oliefera leaves have been reported on various pathogens such as Bacteria (Dzotam et al., 2016), Fungi (Rani et al., 2018; Aondo et al., 2018), Parasite Hegazi et al., (2018), Virus (Mohamed et al., (2017) and also act on physiological disorder such as diabetes (Sivasankari et al., 2014). Indiscriminate use of plants for therapeutic purpose has been quite a common practice especially in Africa including Nigeria (Mansur et al., 2014; Ali et al., 2020). Medicinal plant and herbs are use indiscriminately without proper knowledge of their constituents and dosage (required concentration) that inhibit the growth or kill pathogens without complications and with reduced level of microbes developing resistance. However, there is need to identify active component and respective pharmacological dosage in different medicinal plants as to overcome the increasing trend of microbial resistance and complications. Taking these precedents in to considerations, this study was aimed at examining antifungal activity of the Moringa oleifera leaf crude extract on selected species of fungi (Aspergillus flavus and Rhizopus stolonifer), and assessing the appropriate concentration of the extracts required to inhibit the growth of the test organisms through determination of minimum inhibitory concentration (MIC).

\section{MATERIALS AND METHODS}

\section{Collection and Handling of Leaf Samples}

Fresh Leaves of Moringa oleifera were collected in Federal University Dutse and was identified by Dr. Muhammed Isah Auyo of Biological Science Department. it was confirmed that the collected leaf sample was healthy and uninfected. The dust and other foreign particles were eliminated by washing the collected leaves under running tap water. Leaf samples were air dried at room temperature in the laboratory for 15 days, the dried leaves crushed using mortar and pestle, reduced to powder using warring laboratory blender for 15Minutes at high speed and then stored in airtight bottles until required for extraction (Akinnibosun, 2009). 


\section{Extraction of Powdered Leaves}

A $50 \mathrm{~g}$ of Moringa oliefera powdered leaves were separately extracted in 500mls methanol (methanolic extraction) and ethanol (ethanolic extraction) in $750 \mathrm{ml}$ flat bottom flasks. The mouth of the conical flasks were plugged with rubber corks, then shaken vigorously for 10minutes and kept undisturbed at room temperature for 5 days with occasional manual agitation of the flask using a sterile glass rod after every 24 hours. The two extracts were separately filtered using sterile Whatman no. 1 filter paper. These extracts (methanolic and ethanolic) were stored until required for further process (Ayange-kaa et al., 2015).

\section{Preparation of Sabouraud Dextrose Agar Medium (SDA).}

A Sabouraud Dextrose Agar (SDA) medium was prepared by following manufacturer's instructions by suspending $65 \mathrm{~g}$ of the powder (Titan Biotech LTD) into 1000mls of distilled water. The mixture was boiled to dissolve the medium completely.Well dissolved medium was then sterilized at $121^{\circ} \mathrm{C}$ for 15 minutes and was allowed to cooled to a temperature of $45-50^{\circ} \mathrm{C}$. Furthermore, the medium was supplemented with antibiotic (Chloramphenicol solution) in a ratio of 1:25 to suppress the bacterial growth and dispensed in to sterilized petri-plates (Cheesbrough, 2000).

\section{Isolation of Fungi.}

The test organisms were isolated from contaminated bread by culturing the growth obtained from the contaminated bread on the prepared and dried SDA medium. 1ml of fungal growth suspension $\left(10^{6}\right)$ was inoculated on to each of the Petri plates containing a well dried SDA medium. An antibacterial agent Chloramphenicol $(50 \mathrm{ppm})$ was used to prevent the growth of bacteria. Petri plates were incubated at $37^{\circ} \mathrm{C}$ for 7 days and examined daily for fungal growth (Siva et al., 2008).

\section{Sub-Culturing.}

Fungal colonies that grown on SDA were sub-cultured on fresh SDA for identification. The morphology and cultural characteristics of the growing cultures were observed for preliminary identification. The grown fungal colonies were identified using Microscopic examination (Siva et al., 2008).

\section{Identification of Fungal Species.}

The protocol of (Oyeleke and Marga, 2008) was adopted for the identification of unknown isolate using direct microscopy.The identification was achieved by placing a drop of Lactophenol cotton blue on a clean greased free slide with the aid of a wire loop, where a small segment of mycelium from fungal culture was picked and placed on the drop of normal saline. The mycelium was emulsified on the slide using wire loop. A cover glass was gently applied with a little pressure to remove air bubbles and avoidance of over flowing; the slide was then placed on a Microscope stage and examined with x10 and confirm with $x 40$ objective lenses, respectively. The species observed were identified in-line with the method adopted by Cheesbrough (2000).

\section{Determination of Antifungal Activity of the Extracts against the test Organisms}

Susceptibility of the selected fungal species to the extracts (methanolic and ethanolic) of Moringa oleifera leaves at concentrations of $25 \mathrm{mg} / \mathrm{ml}, 50 \mathrm{mg} / \mathrm{ml}, 100 \mathrm{mg} / \mathrm{ml}, 150 \mathrm{mg} / \mathrm{ml}$ and $200 \mathrm{mg} / \mathrm{ml}$ was carried out using agar well diffusion method adopted from (Ranjit et al., 2014). Sabouraud Dextrose agar was autoclaved at $121^{\circ} \mathrm{C}$ for $15 \mathrm{~min}$ and allowed to cool before pouring on to plates for solidification. A standard sterile cork borer was used to form a well at the center of each inoculated plates and the extract was then introduced into each 
well on the medium. The inoculated plates were then incubated in uninvited position at room temperature for 5 days after which the cultures were observed for zones of growth inhibition. Zones of inhibition were measured with a transparent ruler and recorded in millimeter (Ibrahim et al., 2017).

\section{Determination of Minimum Inhibitory Concentration (MIC)}

Tube dilution technique was used in the determination of minimum inhibitory concentration (MIC) of the test organisms. Nine millilitres $(9 \mathrm{ml})$ of the Sabouraud Dextrose broth was pippetted into various test tubes containing concentrations of $25 \mathrm{mg} / \mathrm{ml}, 50 \mathrm{mg} / \mathrm{ml}$, $75 \mathrm{mg} / \mathrm{ml}$ and $100 \mathrm{mg} / \mathrm{ml}, 150 \mathrm{mg} / \mathrm{ml}$ and $200 \mathrm{mg} / \mathrm{ml}$ of the extract. The overnight culture of the test organisms were added to the test tubes and then incubated at room temperature for 5 days. The lowest concentrations of the extract that did not indicate any visible growth of the incubated organisms in broth culture were taken as the minimum inhibitory concentration (MIC) (Abalaka et al., 2012).

\section{STATISTICAL ANALYSIS}

The data obtained through the experiment were generated in triplicates for each concentration of the extracts. The results of the experiments were recorded as Means \pm Standard deviations $(\mathrm{M} \pm \mathrm{SD})$, the results presented were the average of three determinations.

\section{RESULTS AND DISCUSSION}

\section{RESULTS}

\section{Microscopic and Macroscopic Characteristics of the Test Organisms.}

The summary of identification of test organism is shown in Table 1.The test organisms were identified as described by Cheesbrough (2000).

Table 1: Morphology and Microscopy of Fungal Isolates.

\begin{tabular}{lll}
\hline Morphological description & Microscopic appearance & Fungal isolate \\
\hline $\begin{array}{c}\text { (1)Yellow green, surface with } \\
\text { Reddish brown underneath }\end{array}$ & $\begin{array}{c}\text { Green conidiophores with } \\
\text { septate hyphae }\end{array}$ & A. flavus \\
(2) Black dusty and spongy & $\begin{array}{c}\text { Sporangiospores arises from } \\
\text { Long arching stolons opposite } \\
\text { Rhizoids }\end{array}$ & R. stolonifer \\
\hline
\end{tabular}

\section{Antifungal Activity of the Extract against the test Organisms}

Table 2 and 3 show the potency of the extracts against the test organisms at different concentration of the extract. Both methanolic and ethanolic extracts were more effective against Aspergillus flavus as compared to Rhizopus stolonifer. The average zone of inhibition of the extract against the test organisms at $200 \mathrm{mg} / \mathrm{ml}$ are $12.80 \pm 0.20$ and $9.66 \pm 0.53 \mathrm{~mm}$ for methanolic extract.

Table 2: Antifungal activity of crude Methanolic extract of Moringa oleifera leaves.

\begin{tabular}{lcc}
\hline Test organism & $\begin{array}{c}\text { Concentration of the extract } \\
\mathbf{( M g} / \mathbf{m l})\end{array}$ & $\begin{array}{c}\text { Mean zone of inhibition } \\
\mathbf{M} \pm \mathbf{S D}(\mathbf{m m})\end{array}$ \\
\hline & & \\
Aspergillus flavus & 200 & $12.80 \pm 0.20$ \\
& 150 & $12.00 \pm 0.10$ \\
& 100 & $9.23 \pm 0.50$ \\
50 & $5.34 \pm 0.69$
\end{tabular}




\begin{tabular}{llc} 
& 25 & - \\
Rhizopus stolonifer & 200 & $9.66 \pm 0.53$ \\
150 & $9.40 \pm 0.52$ \\
100 & $6.60 \pm 0.58$ \\
50 & - \\
\hline
\end{tabular}

Key: $\mathrm{M} \pm \mathrm{SD}=$ mean \pm standard deviation, - = no zone of inhibition

Table 3: Antifungal Activity of crude Ethanolic extract showing zones of inhibition at different concentrations

\begin{tabular}{lcc}
\hline Test organism & $\begin{array}{c}\text { Concentration of extract } \\
(\mathbf{M g} / \mathbf{m L})\end{array}$ & $\begin{array}{c}\text { Mean zone of inhibition } \\
\mathbf{M} \pm \mathbf{S D}(\mathbf{m m})\end{array}$ \\
\hline & 200 & $11.40 \pm 0.10$ \\
Aspergillus flavus & 150 & $9.30 \pm 0.32$ \\
& 100 & $7.40 \pm 0.10$ \\
& 50 & $5.10 \pm 0.13$ \\
Rhizopus stolonifer & 25 & - \\
& 200 & $8.67 \pm 0.10$ \\
& 150 & $8.20 \pm 0.32$ \\
& 100 & $7.57 \pm 0.10$ \\
Positive Control & 50 & - \\
(Fluconazole) & 25 & $15.1 \pm 0.86$ \\
Negative control (DMSO) & 10 & 00.00 \\
\hline
\end{tabular}

Key: DMSO = Dimethylsulfoxide

Minimum Inhibitory Concentration of the extract against test organisms

Table 4 and 5 show the smallest inhibitory concentration of the extracts. The minimum inhibitory concentration of the extract revealed to be at lower concentration $(75 \mathrm{mg} / \mathrm{ml})$ against Aspergillus flavus as compared to $(100 \mathrm{mg} / \mathrm{ml})$ Rhizopus stolonifer (table 4)

Table 4: Minimum inhibitory concentration of the crude Methanol extract against the test organisms in $\mathbf{m g} / \mathbf{m l}$

\begin{tabular}{lcccccc}
\hline Test organisms & \multicolumn{6}{c}{ Concentration in $\mathrm{mg} / \mathrm{mL}$} \\
\hline & 25 & 50 & 75 & 100 & 150 & 200 \\
Aspergillus flavus & +++ & + & MIC & - & - & - \\
Rhizopus stolonifer & +++ & ++ & + & MIC & - & - \\
\hline
\end{tabular}

Table 5: Minimum inhibitory concentration of the crude Ethanol extract against the test organisms in $\mathrm{mg} / \mathrm{ml}$

\begin{tabular}{lcccccc}
\hline Test organisms & \multicolumn{7}{c}{ Concentration in $\mathrm{mg} / \mathrm{Ml}$} \\
\hline & 25 & 50 & 75 & $\mathbf{1 0 0}$ & $\mathbf{1 5 0}$ & $\mathbf{2 0 0}$ \\
& & & & & & \\
Aspergillus flavus & +++ & + & MIC & - & - & - \\
Rhizopus stolonifer & +++ & ++ & + & MIC & - & - \\
\hline
\end{tabular}

KEY: $+++=$ Highly Turbid, $++=$ Moderately Turbid, $+=$ Slightly Turbid, $-=$ No Turbidity, MIC=Minimum Inhibitory Concentration.

\section{DISCUSSION}

Aspergillus flavus and Rhizopus stolonifer are presently the most common fungal problems among different age groups, responsible for various infections, including serious lung disease, Aspergillosis and also common pathogen of cereal grains and legumes. 
Methanolic and Ethanolic extracts of Moringa oleifera leaves were tested against Aspergillus flavus and Rhizopus stolonifer and was found to be effective against both tested organisms with variable zones of inhibition, this finding is similar with the findings of (Ganie et al., 2015). But the standard used in the experiment (Fluoconazole) showed greater antifungal activity when compared to the extracts used in the study which agreed with the report of (Abubakar and Usman, 2016) but contrasted with the report of (Bukar et al., 2010), who reported that Moringa oleifera leaves extract showed higher antimicrobial effect than the standard antibiotic used as control in the study. The effect of these extracts on the tested fungal species have been evident to lie in their bioactive constituents which include tannins, alkaloids, flavonoids phenols etc. (Anysor et al., 2011; Onegbu et al., 2020)

The inhibitory properties of the extracts affect the growth of fungi by affecting their metabolism, which may have resulted in their inability to use the required substrate efficiently (Natsir et al., 2019). This is also in line with the statements by (Wang et al., 2016) who reviewed antimicrobial activity and bioactive compound of Moringa oleifera and (Leone et al., 2015) who reported on the antimicrobial characteristics of Moringa oleifera leaf.

Methanolic extract showed maximum activity $(12.80 \pm 0.20 \mathrm{~mm})$ and $9.66 \pm 2.10 \mathrm{~mm}$ at the highest concentration of the extracts used in this research $(200 \mathrm{mg} / \mathrm{ml})$ against Aspergillus flavus and Rhizopus stolonifer respectively, which decreased gradually with the decrease of the concentration of the extract (Table 1). The precedent observations support the results obtained by (Isitua et al., 2016), who studied Invitro effect of Moringa oleifera Lam leaf on some selected Fungal strains.

Ethanolic extract; showed maximum activity $(11.40 \pm 0.10 \mathrm{~mm}$ and $8.67 \pm 0.10 \mathrm{~mm}$ at the highest concentration of the extract used in this study $(200 \mathrm{mg} / \mathrm{ml})$ against Aspergillus flavus and Rhizopus stolonifer respectively, which also decreased with the decrease in the concentration of the extract (Table 1). These observations support the findings of (Oloyede et al., 2012), that decrease in microbial population depends on the concentration of the extract and that high concentration can totally inhibit the growth of microorganisms (Suleiman and Emua, 2009) also reported about toxic effect of plant extract against microorganisms at high concentration.

From these findings, methanolic extract showed greater inhibitory effect against the tested organisms than ethanol, which indicates that methanol extract posses a grater potency against the tested organisms. This is in agreement with (Nwachukwu et al., 2012) who reported that methanol proved to be the good solvents in extracting inhibitory substances from medicinal plant, also (Ashok et al., 2014) revealed that different solvent have different extraction capability.

The possible reasons for the difference in potency of the leaf extract include higher extractability of the active principle in methanol than in ethanol which in turn may affect its concentration per unit volume of the extract (Elgamily et al., 2016). Other factors include extraction method and the synergistic effects between the methanol and the active principle of the leaves (Ashok et al., 2014).

Aspergillus flavus has lower minimum inhibitory concentration and higher zone of inhibition than Rhizopus stolonifer for both the extracts $(75 \mathrm{mg} / \mathrm{ml}$ for Aspergillus flavus and $100 \mathrm{mg} / \mathrm{ml}$ for Rhizopus) which indicates that Aspergillus flavus is more susceptible to both extracts of Moringa oleifera leaves(table 4).This is in agreement with the findings reported by (Nepolean et al., 2009) who assessed the antifungal activity of methanolic and ethanolic extracts of 
Moringa oleifera leaves and reported that; Aspergillus flavus has the higher zone of inhibition for both methanol and ethanol extract. This difference in susceptibility of the test organism to the extracts is due to the differences in nature of fungal strain (Saadabi and Abu, 2011). The result obtained in this study, thus provide a rationale for the use of methanol as solvent for extracting Moringa oleifera leaves for the treatment of Aspergillosis that usually affect immuno compromised individuals and also support the use Moringa oleifera leaves in traditional treatment of Aspergillosis and diseases caused by Rhizopus stolonifer.

\section{CONCLUSION AND RECOMENDATIONS}

The findings obtained in this research showed that; the antifungal activity of the plant extract depend on the type of solvent used for the extraction and the test organisms. Both methanolic and ethanolic extract showed dose dependent antifungal activity. The present study makes the following recommendations:

$>$ Its recommended to isolate and separate the phytochemicals present in Moringa oleifera leaves responsible for this antifungal activity using advance scientific techniques and utilize it in developing synthetic chemotherapeutic agents.

$>$ Findings of the present study support the use of Moringa oleifera leaves in the treatment of diseases caused by Aspergillus flavus and Rhizopus stolonifer.

$>$ Also recommend the use of Methanol can also be use as a solvent for extraction of Moringa oleifera leaves.

\section{REFERENCES}

Abalaka, M., Oyewole, O. A. and Kolawole, A. R. (2012).AntibacterialActivities of Azadirachta indica against Some Bacterial Pathogens, Advances in Life Sciences, 2(2): Pp.5-8.

Abubakar, I., and Usman, A. (2016).Phytochemicals and antibacterial Investigations of Moringa oleifera leaf extract on selected bacterial pathogens. Journal of Microbiology and antimicrobials, 8(5):28-33.

Akinnibosun, H.A. (2009). Biotherapeutic Potential of aqueous and ethanolic extracts of Solenostemun monostachyus (P.Beauv.) Brig. Leaves on some vegetative gramnegative bacteria. Biolological, Environmental. Sciences Journal Tropical. 6(3):33-37.

Ali, M., Sale, M., Sabo, A. and Ibrahim, U.B. (2020).Antimicrobial activity of Jatropha curcas on clinical Isolates from wound infection of Patients Attending Jahun General hospital, Jigawa stste. Nigerian Journal of Microbiology, 34(1):5125-5135.

Aondo, T. O., Odiaka, N. I., Akesa, T. M., and Olaleye, O. O. (2018).Phytochemical and Antifungal Efficacy of Different Parts of Moringa oleifera Plant Extracts. Asian Journal of Biotechnology and Bioresource. 3(2): 1-8, 2018 ISSN: 2457-0125

Ashok, V., Gomashe, P.A., Gulhane, M. P. and Neeta, A.D. (2014). Antimicrobial activity of Indian medicinal plants: Moringa oleifera and Saraca indica, international journal of current Microbiology and applied sciences.6 (3):161-169.

Anyasor, G.N., Aina, D.A., Olushola, M. and Aniyikaye, A.F. (2011). Phytochemical constituent, proximate analysis, antioxidant, antibacterial and wound healing properties of leaf extract ofChromolaena odorata. Ann. Biol. Res., 2: 441-451.

Ayange-kaa, A.B., Hemen, T.J. and Onyezili, N. (2015).The effect of dried leaves extract of Hyptissuaveolens on various stages of Mosquito development in Benue state, Nigeria. IOSR Journal of Pharmacy and biological sciences.10 (6):28-32.

Bukar, A., Uba, A. and Oyeyi, T.I. (2010): Antimicrobial profile of moringa oleifera lam. Extracts against some food - borne microorganisms. Bayero Journal of Pure and Applied Sciences, 3(1): $43-48$. 
Cheesbrough, M. (2000).District Laboratory Practice Manual in Tropical Countries Part 2. Cambridge University Press, Cambridge, 136-137. 158,165, 180.

Dzotam, J.K., Touani, F.K., and Kuete, V. (2016). Antibacterial and antibiotic-modifying activities of three food plants (Xanthosoma mafaffa Lam., Moringa oleifera (L.) Schott and Passiflora edulis Sims) against multidrug-resistant (MDR) Gramnegative bacteria. BMC complementary and alternative medicine.16(1).

Ekor, M. (2014) The. Growing use of herbal medicines: issues relating to adverse reactions and challenges in monitoring safety. Frontiers Pharmacology, 9:463-465.

Elgamily, H., Moussa,A., Elboraey,A., El-Sayed, H., Al-Moghazy,M., and Abdallah , A.(2016).Microbiological assessment of Moringa oleifera extracts and its incorporation in novel dental remedies agains some oral pathogens. Open access journal of medical sciences, 4,585-590.

Ganie A.S., Mudasser, Z., Surender, S. G., Surender, S. Y., Ranjana, S. and Sujata G. (2015).AntifungalEfficacy of Moringa oleiferaLam, American Journal of Phytomedicine and Clinical Therapeutics, 272027019.

Hegazi, A.G, Abdel Megeed, K.N, Hassan, S.E, Abdelaziz, M.M, Toaleb, N.I, El Shanawany, E.E, and Aboelsoued, D. (2018). Comparative ovicidal activity of Moringa oleifera leaf extracts on Fasciola gigantica eggs. Veterinary World, 11(2): 215-220.

Ibrahim, I., Ahmad, M. G., Humaira, Y. M. and Amoo, F. K. (2017). Phytochemical analysis and antimicrobial activity of neocaryamacrophylla leaves extract.International Journal of Health and Life-Sciences, Vol.3 Issue 1, pp.18.

Isitua, C. C., Ibeh, I., and Olayinka, J. N. (2016). In Vitro Antifungal Activity of Moringa Oleifera Lam Leaf on Some Selected Clinical Fungal Strains. Indian Journal of Applied Research. 6 (8) ISSN - 2249-555X | IF: 3.919 | IC Value: 74.50

Leone, A., Spada, A., Battezzati, A., Schiraldi, A., Aristil, J., and Bertoli, S. (2015). Cultivation, genetic, ethnopharmacology, phytochemistry and pharmacology of Moringa oleifera Leaves: An overview. International Journal Molecular Sciences, 16, 12791-12835.

Mansur, I., Sudheer, A., Sambasivarao, K., and Matcha, B. (2014). Antimicrobial activity of Frankincense of B. serrata. International Journal of current Microbiology and Applied Sciences, 3(19): 1095-1101.

Martin, C., Martin, G., Garcia, A., Fernandez, T., Hernández, E., and Puls, L. (2013).Potential applications of Moringa oleifera. A critical review.Pastosy Forrajes2013, 36, 150-158.

Mohamed, A. N., Ahmed, G. A., and Dina, M. B. (2017). Antiviral Potential of Leaf Extracts from Moringa oleifera and Rosemary (Rosmarinus officinalis Lam.). Egypt Journal of Microbiology. 52, pp. 129 - 139.

Natsir, A.W., Wahab, P., Budil, A. R., Arif, R. A., and Arfa, S. R. (2019). Phytochemical and Antioxidant Analysis of Methanol Extract of Moringa and CeleryLeaves, Journal of Physics: Conference Series, 1341: 032023

Nepolean, P., Anitha, J., Emilin, R.R. (2009).Isolation, analysis and identification of phytochemicals of antimicrobial activity of Moringa oleifera Lam. Current. Biotica 3:3339.

Nwachukwu, C. U., Umeh C. N., Kalu, I. G., Okere Slyvester and Nwoko Magnus(2012).Identification And Traditional Uses of Some Common Medicinal Plants In Ezinihitte Mbaise L.G.A., of Imo State, Nigeria, Report and Opinion, Vol. 2(6), P.1.

Oloyede, O.B., Salau, A.K., Akeusola, R.T., Ganiyu, O.T., Azeez, L. and Ogunbode, S.M. (2012). Phytochemical content, Radical Scavenging and antibacterial properties of aqueos extract of Jatropha carcus Linn Leaves. Fountain Journal of natural and applied sciences, $1(1) ; 41-48$. 
Onegbu, V., Nkwoemeka, N., Okey-Ndeche, F. and Obum-Nnadi, C. (2020).Phytochemical and antibacterial Properties of Moringa Oleifera leaf extracts on Escherichia coli and Staphylococcus aureus. Nigerian Journal of Microbiology, 34(1):5145-5152.

Oyeleke, A. and Marga, S.B. (2008).Essential for Laboratory practice (3rd Ed.) Minna, Niger state, Nigeria: Tobest publisher, pg.12-29.

Padayachee, B., and Baijnath, H. (2012).An overview of the medicinal importance of Moringaceae. Journal of Medicinal Plants Resources 6, 5831-5839.

Pan, S.Y., Zhou, S-F., Ga, S-H., et al. (2013). New perspectives on how to discover drugs from herbal medicines: CAM's outstanding contribution to modern therapeutics, Evidence Based Complement Alternative Medicine 627375

Rani, N., Husain, K., and kumolosasi, E. (2018).Moringa genus: A review of phytochemistry and Pharmacology. Frontiers of Pharmacology, 9,108.

Ranjit, R.R., Ajit, R.S. and Bhagyashree, B. J. (2014). Antimicrobial activity of Azadirachta indica (Neem) against Pathogenic microorganisms. Journal of Academia and industrial Research.3 (7): 327-329.

Saadabi A. M. and Abu Z.A.I. (2011).An in vitro antimicrobial activity of Moringa oleifera L. seed extracts against different groups of microorganisms. Asian Journal of Basic and Applied. Science 5:129-134.

Saini, R., K. (2015) Studies on enhancement of carotenoids folic acid iron and their bioavailability in Moringa oleifera and in vitro propagation. Mysore: University of Mysore. . 6(8):145-149.

Saini, R.K., Shetty, N.P., Giridhar, P. (2014). Analysis of fatty acids in Indian cultivars of Moringa oleifera: potential sources of PUFA. Journal American Oil Chemist Society. 91:1029-1034.

Siva, N., Ganesan ,S., Banumathy,N. and Muthuchelian, M.(2008) Antifungal effects of leaf extract of some medicinal plant against Fusarium oxysporum causing wilt disease of Solanum melogena L. Ethanobotanical Leaflets, 12:156-163.

Sivasankari, B., Anandharaj, M.,and Gunasekaran, P.(2014).An ethnobotanical study of indigenous knowledge on medicinal plants used by the village peoples of Thoppampatti, Dindigul district, Tamilnadu, India. Journal Ethnopharmacology., 153, 408-423.

Stohs, S. and Hartman, M. J. (2015).Review of the Safety and Efficacy of Moringa oleifera. Phytotherapy Resources. 29, 796-804.

Suleiman, M. N. and Emua, S. A. (2009). Efficacy of four plants extracts in the control of root rot disease of cowpea (Vigna unguiculata[L.] Walp). African Journal Biotechnology. 8: 3806380.

Wang, L., Chen, X., Wu, A. (2016). Mini Review on Antimicrobial Activity and Bioactive Compounds of Moringa oleifera. Journal of Medicinal Chemistry (Los Angeles) 6: 578-582. 